\title{
Primerjava med postopki nacionalnih in mednarodnih posvojitev v Sloveniji in na Hrvaškem
}

\begin{abstract}
Predstavljenajeraziskavassocialnimidelavkamizizkušnjamipripostopkih posvojitevin postopkih meddržavnih posvojitevv RepublikiSloveniji in Republiki Hrvaški. Namen raziskaveje bil prikazati razlike in podobnosti med postopkoma v obeh državah, raziskati reproduktivne pravice žensk, prikazati najnovejšestatistične podatke, pregledatiperspektivo otrokin potencialnih posvojiteljev na sam postopek, se seznaniti s posebnostmi na tem področju in predvsem ponuditi predloge, kako učinkovitejše delovati na področju posvojitev.

Ključne besede: centri za socialno delo, otrokove pravice, reproduktivne pravice, splav, antirasizem, posvojitelji.

Kristina Urhjeleta 2020 diplomiralana Fakultetizasocialno delo Univerzev Ljubljani. Podiplomski študij nadaljuje na Pedagoški fakulteti Univerze na Primorskem v Kopru, smer Inkluzivna pedagogika. Kontakt: kristina.urh@gmail.com.
\end{abstract}

\section{Comparison between the processes of national and international adoptions in Slovenia and Croatia}

\begin{abstract}
A research on social workers with experience in intra- and intercountry adoption procedures in the Republic of Slovenia and the Republic of Croatia is presented. The purpose of the research was to show the differences and similarities between the two procedures in both countries, to relate to women's reproductive rights, to show the latest statistics, to review the perspective of children and potential adopters on the procedure and, above all, to come up with proposals on how to work more effectively in the field of adoptions.
\end{abstract}

Keywords: centres for social work, children's rights, reproductive rights, abortion, anti-racism, adopters.

Kristina Urh completed her university studies at the Faculty of Social Work, University of Ljubljana, in 2020. She is continuing her postgraduate studies at the Faculty of Education of the University of Primorska in Koper, majoring in Inclusive pedagogy. Contact: kristina.urh@gmail.com.

\section{Uvod}

Zaviršek (2012) posvojitev definira kot kompleksen in vseživljenjski proces. Je osebno dejanje osebe, zakoncev ali zunajzakonskih partnerjev in hkrati pravno-formalni postopek, ki ga opravljajo socialne službe. S posvojitvijo se povežejo družina, ki je posvojila otroka, biološka družina in otrok. Je ena izmed najbolj znanih in tudi ena izmed najstarejših oblik socialnega starševstva. Pri posvojitvah mora biti osnovno vodilo, da se otroku poišče najprimernejše nadomestilo staršev glede na njegove potrebe, starost in druge okoliščine (Zaviršek, 2012).

Motivi za posvojitev otroka na Hrvaškem so podobni kot v Sloveniji: neplodnost zakoncev, želja po večjem številu otrok, pomoč otrokom in drugi altruistični razlogi. 


\section{Uporabljena metodologija}

\section{Vrsta raziskave}

Izvedena raziskava je kvalitativna, saj so vrednosti spremenljivk navedene z besedami, dobljeni podatki pa so tudi obdelani in analizirani na besedni način (Mesec, 2017/2018, str. 11). Raziskava je poizvedovalna (eksplorativna), saj so bili nameni odkriti probleme, jih formulirati in s preučevanjem manjšega števila primerov oblikovati preverljive hipoteze. Prav tako je raziskava empirična, saj sem zbirala novo, izkustveno gradivo (Mesec, Rape Žiberna in Rihter, 2009 , str. 80,84), in primerjalna, ker sem obravnavala vzorce podobnosti in različnosti postopkov posvojitve $\mathrm{v}$ dveh državah, da bi ugotovila razlike $\mathrm{v}$ postopkih (Hafner Fink, 2007, str. 117-120).

\section{Merski inštrument in viri podatkov}

Metoda raziskovanja je spraševanje oziroma intervju, merski inštrument pa je delno strukturiran vprašalnik, saj sem po potrebi odgovore prilagajala pogovorom oziroma sogovornicam (Mesec, Rape Žiberna in Rihter, 2009, str. 230). Vprašalnik je sestavljen iz petnajstih vnaprej pripravljenih vprašanj. Pripravila sem ga sama na podlagi predhodnega znanja in izkušenj, pridobljenih med študijem in praktičnim usposabljanjem. Viri podatkov so intervjuji in odgovori na vprašanja.

\section{Populacija in vzorčenje}

Populacija opravljene raziskave so bili zaposleni socialni delavci na vseh centrih za socialno delo v Sloveniji in vseh centrih za socialno skrb na Hrvaškem, ki od 1. 11. 2019 delujejo na področju posvojitev. Vzorec moje raziskave je pet socialnih delavk, ki delujejo na področju posvojitev na Centru za socialno delo Primorsko-Notranjska, enota Ilirska Bistrica, in pet socialnih delavk, ki delujejo na področju posvojitev na Centru za socialno skrb Reka (Hrvaška). Vzorec moje raziskave je neslučajnostni in priročni, ker sem osebe za intervjuje iskala na meni najpreprostejši in najdostopnejši način, torej prek telefonskih klicev in v bližini mojega kraja bivanja.

\section{Zbiranje podatkov}

Podatke sem zbirala v desetih intervjujih. Intervjuvanke sem za sodelovanje prosila najprej prek telefona. Intervjuje sem opravljala po vnaprej dogovorjenem terminu od 15. do 31. januarja 2020 v prostorih Centra za socialno delo Primorsko-Notranjska, enota Ilirska Bistrica, in na Centru za socialno skrb na Reki. Intervjuje sem izvedla osebno z neposrednim spraševanjem. Vsak intervju je trajal približno 20 minut. Intervjuvanke so si pri vprašanjih vzele čas za premišljevanje.

\section{Obdelava in analiza podatkov}

Za obdelavo in analizo podatkov sem uporabila metodo kvalitativne analize. Intervjuje sem najprej dobesedno prepisala in uredila v wordovem dokumentu. Pri jeziku sem ohranila pogovorni jezik intervjuvank in pogovorov v originalu 
nisem prevajala. Pazila sem, da besedam nisem spremenila pomena, zato je bil moj poseg $v$ intervjuje minimalen. Za raziskavo sem uporabila celotne stavke sogovornic in jih potem uporabila za analizo, razpravo in sklep. Za namene obdelave in analize podatkov sem se pogovarjala s Centrom za socialno delo Primorsko-Notranjska, enote Ilirska Bistrica, Postojna in Cerknica, s Centrom za socialno skrb na Reki, Hrvaškim zavodom za javno zdravje, Inštitutom za javno zdravje (NIJZ), z našim MDDSZ, s hrvaškim MDOMSP, z Ministrstvom za notranje zadeve RS, Statističnem uradom RS ter z društvi Na drugi način, Adopta in Deteljica.

\section{Rezultati}

\section{Postopek posvojitve}

Ugotovitve o postopku posvojitve v Sloveniji in na Hrvaškem sem strnila v deset točk.

Prvič, poglavitni pravni vir na področju posvojitev v Republiki Sloveniji je Družinski zakonik (2019), posvojitve na Hrvaškem pa ureja Obiteljski zakon (2015). Za posvojitve je na Hrvaškem pristojen center za socialno skrb (v izvirniku centar za socijalnu skrb; ima enake pristojnosti kakor slovenski centri za socialno delo) kot javna ustanova, ki jo je ustanovilo Ministrstvo za demografijo, družino, mlade in socialno politiko, ki ureja socialno varstvo. Med samo izvedbo postopka posvojitve v Sloveniji in na Hrvaškem tako ni vidnih razlik.

Drugič, pomembno je omeniti, da slovenska zakonodaja ne določa odprte posvojitve. To pomeni, da nimajo vsi udeleženi (biološka mati oziroma družina, otrok in potencialni posvojitelji) pravice do resnice. Otrok je za oblikovanje ustrezne identitete prisiljen izvedeti resnico o svojem izvoru. Prav tako rezultati kažejo, da včasih stik z biološko materjo otroku koristi in ne škodi (Klun, 2008, str. 21). Rapoša Tanjšek meni, da je odprta posvojitev edini možni koncept socialnega dela v odnosu do vseh treh udeležencev (Tanjšek Rapoša idr., 2002 str. 2). V hrvaški zakonodaji pa je določeno, da ima otrok pravico, da od staršev, ki so ga posvojili, izve, da je posvojen. Posvojitelji so tako dolžni otroku najpozneje do sedmega leta starosti na primeren način povedati, da je posvojen, če je otrok starejši, pa takoj po posvojitvi. Odprta posvojitev je na Hrvaškem uzakonjena (Obiteljski zakon, 2015, 206. člen).

Tretjič, enakost oziroma podobnost med postopkoma je opazna tudi, če bi otroka hotela posvojiti istospolna partnerja, saj takšna posvojitev ni dovoljena ne v Sloveniji ne na Hrvaškem. Zakon o registraciji istospolne partnerske skupnosti (2005) in Zakon o životnom partnerstvu osoba istog spola (2014) ne urejata razmerij partnerja do otrok. V slovenskih istospolnih skupnostih je dovoljena enostranska posvojitev, torej lahko vsak od registriranih istospolnih partnerjev s soglasjem partnerja posvoji njegovega otroka (Zaviršek, 2012, str. 66). Na Hrvaškem bi bilo najpomembneje določiti jasne zakone in pravilnike, ki bi regulirali možnost istospolnih partnerjev za posvojitev otrok (Sedlar, 2017). Dogaja se, da strokovne osebe ali zdravstveni delavci niso dovolj informirani, izobraženi in ne poznajo posebnosti posvojitev. Na Hrva- 
škem restriktivni zakonski in institucionalni okviri podpirajo diskriminacijo istospolnih družin. Istospolno usmerjeni ljudje želijo postati starši zaradi istih razlogov kot heteroseksualna večina. Po podatkih (Martinović, 2020) si 80 $\%$ vseh ljudi želi postati starš, pri istospolno usmerjenih pa je ta odstotek le $46 \%$. Večina se jih odreče želji po starševstvu zaradi zakonskih in družbenih omejitev, ki jih doživljajo istospolno osebe pri načrtovanju družine.

Četrtič, omejitve in zahteve glede samega postopka posvojitve so tako v Sloveniji kot na Hrvaškem enake. Razlika je v tem, da imajo na Hrvaškem šolo za potencialne posvojitelje (Udruga »Na drugi način«, b. d.) in več otrok, ki bi jih starši lahko posvojili, saj je v domovih za otroke veliko otrok, to pa kaže na slabo urejenost reproduktivnih pravic žensk in močnejši vpliv patriarhata. Največja razlika se kaže v organih odločanja. V Sloveniji ima to pristojnost sodišče, ki upošteva mnenje centra za socialno delo, na Hrvaškem pa postopek v celoti vodijo centri za socialno skrb.

Petič, celoten postopek posvojitve je po pripovedih socialnih delavk iz obeh držav izjemno dolgotrajen. V Sloveniji traja od štiri do osem let, na Hrvaškem pa od enega do treh let. Razlogi so različni, omenim lahko najpomembnejše, kot so pomanjkanje rokov, neorganiziranost centrov, hitrost obdelane dokumentacije, nekoordinacija različnih strokovnjakov in pa tudi to, koliko otrok je trenutno vpisanih v evidenco posvojitev. Med raziskovanjem sem ugotovila, da to, da ni otrok za posvojitev, ne smemo jemati kot problem.

Šestič, rasizem je ideologija ali praksa, ki se kaže v moči in dozdevni večvrednosti ene skupine nad drugo zaradi rase, barve kože, nacionalnosti ali kulture. Rasizem se manifestira na individualni, skupinski in institucionalni ravni. Ima ključno vlogo pri krepitvi socialne kontrole nad deprivilegiranimi ljudmi in ima eno od ključnih mest v sistemu državne blaginje (Dominelli, 1995, str. 183-184). Potencialni starši se v Sloveniji srečujejo predvsem z vsakdanjim rasizmom, ki se na prvi pogled zdi zelo nedolžen. Zanj so značilni buljenje, dotikanje, denormalizacija v obliki vprašanj, pripisovanje določenih značilnosti ali spretnosti in pa poudarjanje teh etničnih posebnosti otroka (Zaviršek, 2012, str. 189). V kontekstu posvojitev, predvsem meddržavnih, so nekateri otroci (npr. romski, hendikepirani) obravnavani drugače oziroma so diskriminirani. Takšni otroci gredo tudi težje v posvojitev, saj jih ljudje ne želijo posvojiti. Pojavljajo se torej predsodki staršev. Nekateri potencialni starši so otroka odklonili zaradi znamenj hendikepa, barve kože in las. To lahko povežemo s sodobnim rasizmom, ki se v javnosti ne kaže (Klun, 2008, str. 49-50).

Na Hrvaškem uporabljajo izraz multikulturno delo, ki vsebinsko ustreza našemu pojmovanju antirasističnega socialnega dela. Kot sestavni del multikulturnosti bi morali problematizirati strukturne neenakosti, saj so odgovorne za večanje etničnih razlik pri razvijanju kulture skupin. Vse dokler neenakosti ne bodo odpravljene, etnično kompetentno delo ne bo moglo graditi mostov čez kulturne ovire. Pri tem bodo socialni delavci morali usvojiti spretnosti kulturne kompetentnosti, saj bodo le tako lahko razumeli drugačne poglede na svet, načine reševanja problemov, različne načine življenja, vrednote in etiko pripadnikov drugih kultur. Multikulturno delo po mojem mnenju na Hrvaškem ni tako napredno kot v nekaterih drugih državah Evrope, ki so 
bolj dovzetne za kulturne razlike. Socialni delavci kot pomočniki, sodelavci, aktivisti ali strokovnjaki se bodo morali prilagoditi vedno več novim uporabnikom, ki jih bo zaznamovala ne samo socialno-ekonomska situacija, ampak tudi kulturna pripadnost (Žganec in Miljenović, 2011, str. 324-326).

V Sloveniji in na Hrvaškem si socialne delavke in delavci prizadevajo, da bi svoje delo opravili v skladu s antirasistično prakso socialnega dela. Zavzemati se morajo za zmanjševanje ekonomske in socialne izključenosti, za t. i. pozitivno diskriminacijo. Antirasistično socialno delo je metoda socialnega dela, ki poskuša odpraviti strukturne neenakosti, ki jih vzdržuje rasizem. Cilj je deprivilegiranim zagotoviti potrebne storitve v strokovnem odnosu, ki jim omogoča, da nadzorujejo svoje življenje (Dominelli, 1995, str. 190). Naslednji korak pri antirasistični praksi socialnega dela je tudi poznavanje zakonodaje, ki strokovnjake vodi pri njenem uresničevanju. Uporabljati je treba metode socialnega dela, kot so zagovorništvo, individualno načrtovanje, terensko delo, ki strokovnjakom pomagajo pri uresničevanju dobre prakse (Zorn, 2003, str. 307-308).

$\mathrm{V}$ državah je rasizem viden predvsem pri potencialnih posvojiteljih in $\mathrm{v}$ okolju. Na Hrvaškem je odprtost za posvojitev otrok iz druge kulture ali rase vse opaznejša prav zaradi širšega sprejemanja omenjene multikulturnosti v družbi in zaradi promocije vedno več uspešnih posvojitev iz drugih držav prek medijev, zgodb drugih potencialnih posvojitev ipd. (Blažeka Kokorić, 2019, str. 100). Razlike glede antirasistične prakse med Slovenijo in Hrvaško so minimalne. Na Hrvaškem si socialna politika prizadeva predvsem za kulturno kompetentnost socialnih delavcev, saj se zavedajo, da je to področje, na katerem jim znanja primanjkuje. Obe državi si prizadevata za čim več izobraževanja socialnih delavcev in drugih strokovnjakov na področju posvojitve. V Sloveniji je antirasistična praksa bolj razdelana, ni omejena samo na kulturno kompetentnost socialnih delavcev, ampak si prizadeva, da bi se tudi v celoti izvajala. Opaziti je, da si na Hrvaškem prizadevajo za širjenje medkulturne kompetentnosti tudi med druge strokovnjake.

Sedmič, reproduktivna pravica žensk do splava je povezana tudi s posvojitvami. Gre za svobodno odločitev za razmnoževanje (kdaj, kolikokrat), informiranost in dostopnost do varnih in učinkovitih metod za načrtovanje družine. Pomembni so njihova cenovna dostopnost, dostopnost do drugih metod, ki so z zakonom določene, dostop do ustrezne zdravstvene oskrbe za varno nosečnost, svetovanje glede spolno prenosljivih bolezni in celotno seksualno zdravje s ciljem kakovostnega življenja (Buda, 2017, str. 10-11). Pomembna razlika med državama je, da na Hrvaškem reproduktivne pravice žensk niso dosledno upoštevane. Problem, ki se pojavlja v zadnjih letih na Hrvaškem, je, da Zakon o liječništvu (2003), Zakon o sestrinstvu (2003) in Zakon o ljekarništvu (2003) urejajo tudi pravico do ugovora vesti zdravstvenih delavcev (osebni pogovor z Eneo Maćašić s Centra za socialno skrb Rijeka, 20.11. 2019).

Neustrezna državna regulacija, zdravniška korupcija, izkoriščanje položaja, spremenljivost cen posega na črno, pomanjkanje evidenc in ugovor vesti so samo nekatere od neregularnosti hrvaškega zdravstvenega sistema, s katerimi se srečujejo ženske, ki želijo prostovoljno prekiniti nosečnost. Danes splav tam sodi v t. i. sivo cono, saj je zakonsko dovoljen, v praksi pa njegovo izvajanje ni preprosto. 
Prekinitev nosečnosti tako lahko opravijo v katerikoli bolnišnici, ki ima oddelek za ginekologijo in porodništvo, ampak še vedno ni na voljo v vseh. V nekaterih bolnišnicah zdravniki zaradi lastne vesti in pomanjkljivosti v zakonu splavov ne izvajajo. Po nekaterih informacijah nekateri zdravniki splave izvedejo na črno in zanje zaračunajo ceno, ki jo sami določijo in ni zakonsko regulirana. Ženske pa razumejo »skrivni« splav kot priložnost, da so manj izpostavljene različnim predsodkom okolice. Prav patriarhalna stigmatizacija je eden od poglavitnih razlogov za to, da je splav na Hrvaškem tabu. Dokler družba na Hrvaškem ne izstopi iz patriarhalnih socialnih norm, je nemogoče pričakovati napredek, povezan s tem, da bi se pravica do splava tudi ustrezno izvajala (Knežević, 2015).

Ocenjuje se, da na Hrvaškem več kot 300.000 žensk nima pristopa do primerne ginekološke oskrbe, cene zasebnih ginekoloških ordinacij pa se zvišujejo. Vse več Hrvatic odhaja opravit splav v Slovenijo. Na začetku leta 2019 se je na Hrvaškem število žensk, ki so prišle opravit splav v Brežice, povečalo za $25 \%$ (Indeks, 2019a). V Sloveniji splav zavrne $3 \%$ ginekologov, na Hrvaškem pa kar $60 \%$. Na Hrvaškem je prekinitev nosečnosti ženskam, katerih nosečnost je posledica posilstva, zavrnjena, pa čeprav imajo po zakonu pravico do njega. Splav na Hrvaškem bo postal še težje dostopen. Leta 2017 so v Saboru (hrvaškem parlamentu) sprejeli odlok o novem Zakonu o splavih, ki pa do danes še ni sprejet (Indeks, 2019b).

Podatki, pridobljeni od podatkovnega portala slovenskega Inštituta za javno zdravje (2020) in Hrvaškega zavoda za javno zdravstvo (2020), kažejo, da je število splavov različno glede na leto. V Sloveniji so razlogi za zmanjševanje splavov: upoštevanje reproduktivnih pravic žensk, šolska izobraževanja o varni spolnosti in regulacija zakonov, ki upošteva reproduktivne pravice žensk. Tudi na Hrvaškem se število splavov zmanjšuje, a je vedno pogostejša praksa izvajanje splavov na črno. Reproduktivne pravice žensk niso v celoti upoštevane, vidni so ekonomski in ideološki pritiski, ker država nima posluha za takšne probleme. Reproduktivne pravice žensk je tako v Sloveniji kot na Hrvaškem možno zaščititi le s kolektivnimi akcijami, premišljeno politiko ter razvijanjem globalnih strategij in nacionalnih inovacij (Geiger, 2006, str. 110-111).

Preglednica 1: Število splavov v Sloveniji in na Hrvaškem v letih 2012-2018.

\begin{tabular}{|l|l|l|}
\hline LETO & ŠTEVILO SPLAVOV V SLOVENIJI & ŠTEVILO SPLAVOV NA HRVAŠKEM \\
\hline $\mathbf{2 0 1 2}$ & 4.106 & 10.088 \\
\hline $\mathbf{2 0 1 3}$ & 4.011 & 8.922 \\
\hline $\mathbf{2 0 1 4}$ & 4.060 & 9.103 \\
\hline $\mathbf{2 0 1 5}$ & 3.682 & 8.362 \\
\hline $\mathbf{2 0 1 6}$ & 3.736 & 6.904 \\
\hline $\mathbf{2 0 1 7}$ & 3.529 & 6.145 \\
\hline $\mathbf{2 0 1 8}$ & 3.474 & 7.064 \\
\hline
\end{tabular}

Vira: Nacionalni inštitut za javno zdravje (2020) in Hrvaški zavod za javno zdravstvo (2020)

Osmič, izzive in težave pri samem postopku posvojitve socialne delavke doživljajo drugače. Pomanjkanje otrok za posvojitev je v Sloveniji dejstvo, ki pomeni izziv 
za družbo. Prav tako je izziv pomanjkanje financ, na katerega socialne delavke nimajo vpliva. Rejništva, ki so po mnenju socialnih delavk predolga, bi morala veljati kot začasni krizni ukrep. Na Hrvaškem so socialne delavke poudarile težavne in nepripravljene potencialne posvojitelje na samo posvojitev otroka. $\mathrm{V}$ Sloveniji obstaja sodelovanje med različnimi strokovnjaki, vendar ti med seboj ne sodelujejo dobro, na Hrvaškem pa je primer dobre prakse pokazal prav nasprotno, saj jim sodelovanje z drugimi strokovnjaki prinaša olajšanje pri delu.

Devetič, strokovnost in odlike socialnih delavk so na področju posvojitev ključne. Poleg sočutja, privrženosti, izkušenj na področju posvojitev, vsestranskosti in organiziranosti so najpomembnejši prav sposobnost za komunikacijo, smisel za humor in vztrajnost.

Desetič, Slovenija in Hrvaška med seboj ne sodelujeta. Socialne delavke so poudarile, da ima Slovenija malo vpisanih otrok v mednarodni evidenci posvojitev in da večkrat sodeluje s Češko, Bolgarijo, Makedonijo, Bosno in Hercegovino ter Rusijo, sistem na Hrvaškem pa je zasnovan tako, da veliko otrok ostane $\mathrm{v}$ domovih za otroke in ne gredo $\mathrm{v}$ posvojitev.

Pomanjkanje raziskovanja na področju rejništva in oviran razvoj Hrvaške zaradi vojne $\mathrm{v}$ devetdesetih letih sta pripomogla $\mathrm{k}$ temu, da se stvari niso razvijale $\mathrm{v}$ skladu $\mathrm{z}$ otrokovimi potrebami kot tudi ne $\mathrm{v}$ skladu $\mathrm{z}$ rejniškimi in biološkimi družinami otrok. Javna skrb za otroke na Hrvaškem danes ne temelji na jasnem teoretskem modelu. To vpliva na prakso zagotavljanja psihosocialnih storitev na tem področju. Domovi za otroke so danes po sodobnih standardih oskrbe preveliki, imajo zastarelo organizacijsko obliko in premalo strokovnih delavcev, zato bi jih bilo treba nujno prenoviti. Na Hrvaškem je med bivanjem otrok v instituciji in zunaj nje predvideno in želeno razmerje $20 \%: 80 \%$. V skladu s tem razmerjem je v sklopu deinstitucionalizacije treba otrokom zagotoviti bivanje v rejniških družinah, katerih število in kakovost se morata povečati s pomočjo večjega vlaganja na področje rejništva, in transformirati obstoječe ustanove, ki imajo manjšo kapaciteto. Treba si je prizadevati tudi za razvoj specializiranega rejništva za najmlajše in otroke s težavami v razvoju (Laklija, 2011, str. 292-293).

V Sloveniji je pravica otroka do bivanja zunaj institucije v celoti upoštevana. Domov za otroke ni. Otroci in mladoletniki, za katere starši ne skrbijo, ki nimajo staršev ali so brez družinske oskrbe, uživajo posebno varstvo in skrb države. Družinski zakonik (2019) določa, da država zagotavlja varstvo mladoletnim otrokom vselej, kadar je ogrožen njihov zdrav razvoj in kadar to zahtevajo druge koristi otrok. Oblike varstva, ki ga Družinski zakonik določa, so: posvojitev otroka, namestitev v rejniško družino in skrbništvo. Katera oblika varstva je za določenega otroka najprimernejša, je odvisno od vsake konkretne situacije posebej, o tem pa odloča sodišče (osebni pogovor s Tanjo Oberski z Ministrstva za delo, družino, socialne zadeve in enake možnosti, 24. 4. 2020).

\section{Postopek na področju meddržavnih posvojitev}

Postopek mednarodne posvojitve je v obeh državah enak - vodi ga pristojno ministrstvo. Na leto je v obeh državah le nekaj mednarodnih posvojitev. Slove- 
nija sodeluje predvsem s Češko, Bolgarijo in Makedonijo, zadnja leta pa otroci prihajajo tudi iz Rusije, Gvineje, Bosne in Hercegovine ter Gane. Na Hrvaškem pa zelo pogosto posvojijo otroka iz Afrike, v vseh letih je evidentiran le en primer posvojitve otroka iz Tajske (osebni pogovor z Ivano Ištuk s hrvaškega ministrstva za družino, 17.4. 2019). Skupno meddržavnim posvojitvam v obeh državah je to, da imajo centri manj dela, starši pa več. V raziskavi sem ugotovila, da so potencialni posvojitelji naleteli na nepoznavanje samega postopka mednarodne posvojitve pri strokovnih delavcih. Postopki meddržavnih posvojitev so v obeh državah bolj zamudni zaradi različnih notranjih organizacij držav. Ni sprejetih dodatnih sporazumov, socialne delavke pa nimajo dovolj izkušenj oziroma niso dovolj informirane.

Preglednica 2: Število notranjih in meddržavnih posvojitev v Sloveniji in na Hrvaškem v letih 2012-2019.

\begin{tabular}{|c|c|c|c|c|}
\hline Leto & $\begin{array}{c}\text { Število vseh } \\
\text { posvojitev (Slo- } \\
\text { venija in tujina) }\end{array}$ & $\begin{array}{c}\text { Št. posvojitev v Sloveniji } \\
\text { (voklepaju je število } \\
\text { enostranskih posvojitev } \text { *) }\end{array}$ & $\begin{array}{c}\text { Št. posvojitev } \\
\text { iz tujine }\end{array}$ & $\begin{array}{c}\text { Število vseh posvojitev } \\
\text { na Hrvaškem }\end{array}$ \\
\hline 2012 & $\mathbf{7 0}$ & $35(18)$ & 35 & $\mathbf{1 1 1}$ \\
\hline 2013 & $\mathbf{4 3}$ & $28(19)$ & 15 & $\mathbf{1 0 7}$ \\
\hline 2014 & $\mathbf{4 5}$ & $31(18)$ & 14 & $\mathbf{1 1 3}$ \\
\hline 2015 & $\mathbf{3 9}$ & $24(15)$ & 15 & $\mathbf{1 2 6}$ \\
\hline 2016 & $\mathbf{4 5}$ & $34(17)$ & 11 & $\mathbf{1 0 5}$ \\
\hline 2017 & $\mathbf{5 4}$ & $40(24)$ & 14 & $\mathbf{1 3 2}$ \\
\hline 2018 & $\mathbf{4 5}$ & $31(20)$ & 14 & $\mathbf{1 1 7}$ \\
\hline 2019 & $\mathbf{4 5}$ & 30 & 15 & \\
\hline
\end{tabular}

Viri: osebna pogovora s Tanjo Oberski z MDDSZ 4. 11. 2019 in 15. 5. 2020, osebni pogovor z Dobrilo Miletić s hrvaškega ministrstva za družino 13. 11. 2019 in osebni pogovor z Ivano Ištuk s hrvaškega ministrstva za družino 17. 4. 2019.

Na podlagi podatkov je mogoče sklepati, da je v Sloveniji več mednarodnih posvojitev kot na Hrvaškem. Na Hrvaškem pa je več notranjih posvojitev. V zadnjih sedmih letih je bilo v Sloveniji 18 posvojitev na 100.000 prebivalcev, na Hrvaškem pa 21 posvojitev na 100.000 prebivalcev.

\section{Spremembe na področju posvojitev}

Na področju posvojitev bi se morale zgoditi sistemske spremembe. Da bi se v praksi implementiralo načelo zaščite najboljšega interesa otrok v samem postopku posvojitve, je treba zagotoviti ne samo kakovosten zakonski okvir, ampak tudi temeljite standarde izvajanja posameznih strokovnih postopkov med posvojitvijo. Druge spremembe se nanašajo na skrajšanje rejništva, 
izboljšanje zakonodaje, cenejše postopke meddržavnih posvojitev in na zmanjševanje birokratskih ovir. Transformacija bi se morala zgoditi na ravni miselnosti, ki je ena izmed nujnih sprememb, saj se vsi vključeni v postopek posvojitve srečujejo z izzivi sodobnega časa. Posvojitve ne bi smele biti tabu, o njih se je treba pogovarjati, spremeniti je treba stališče družbe, predvsem do romskih otrok, in pare opogumiti. Pomembno bi bilo izpopolniti register otrok z jasnejšimi kategorijami težav, s katerimi se srečujejo otroci, izboljšati kakovost strokovnih ocen primernosti potencialnih posvojiteljev, protokol in pravilnik o postopku posvojitev, uvesti nove inovativne pristope pri prepoznavnosti otrok in podpreti potencialne posvojitelje.

\section{Dodatno izobraževanje}

Socialne delavke iz obeh držav vse informacije dobijo neposredno s pristojnega ministrstva, ki jih obvešča o spremembah v zakonodaji, ki so za delo relevantne. Informacije se navezujejo tudi na število otrok in število potencialnih posvojiteljev ter na njihove značilnosti. V manjši meri te informacije dobijo tudi od nevladnih organizacij in z medsebojnim sodelovanjem. Socialne delavke, ki delujejo na področju posvojitev, pri svojem delu najbolj pogrešajo izkušnje in dodatno usposabljanje. Socialne delavke iz obeh držav so bile pri izražanju želja glede izobraževanja na področju posvojitev dokaj enotne. Želijo si več informacij iz same prakse. S tem namenom bi si želele aktiv za posvojitev, ki bi združeval socialne delavke iz vseh centrov in tesnejše sodelovanje med njimi. Predvsem bi si želele več informacij in dodatnega izobraževanja že na sami študijski poti in pozneje pri samem delu.

\section{Sklep in predlogi}

$\mathrm{Z}$ raziskavo in pregledom literature o notranjih in mednarodnih posvojitvah sem ugotovila, da so posvojitve eden od pomembnejših upravnih postopkov, ki jih vodijo centri za socialno delo. Postopki so v obeh državah zamudni, potrebujejo veliko pravne dokumentacije, pogovorov in časa. Slovenija in Hrvaška med seboj ne sodelujeta, saj obe državi iščeta otroke za posvojitev. $\mathrm{Z}$ raziskavo sem ugotovila, da med postopkoma posvojitve $v$ Sloveniji in na Hrvaškem ni občutne razlike.

Glede na preučeno teorijo, opravljeno raziskavo in izkušnje iz prakse na centru za socialo delo podajam nekaj predlogov za boljše delovanje socialnih delavk na področju posvojitev. Priporočljivo bi bilo več medsebojnega sodelovanja med socialnimi delavkami. Med skupno sodelovanje sodi tudi sodelovanje z drugimi strokovnjaki, ki sodelujejo pri postopku posvojitev, kot so »team buildingi « in skupne supervizije. Prav tako bi bilo dobro sodelovati in komunicirati s socialnimi delavkami na drugih centrih, tudi tistimi v tujini. Za lažje sodelovanje med samima državama bi bilo treba dopolniti znanje na področju sistema in zakonodaje tuje države. Potencialne posvojitelje bi bilo treba dodatno informirati o samem postopku in izzivih, ki se lahko pojavljajo v postopku posvojitve. Pomembno bi bilo določiti univerzalna navodila in 
skupne sestanke. Dobrodošlo bi bilo tudi izobraževanje oziroma dodatno usposabljanje na področju posvojitev. Potrebnih je več informacij iz same prakse, torej neposredne izkušnje drugih centrov in socialnih delavk. $\mathrm{S}$ tem namenom bi bili potrebni aktivi za posvojitev, ki bi vključevali socialne delavke iz več centrov za socialno delo. Več informacij bi bilo treba pridobiti tudi na sami Fakulteti za socialno delo, saj bi se tako lahko izognili etičnim dilemam pri mlajših socialnih delavkah. Za konec bi bilo priporočljivo boljše sodelovanje z nevladnimi organizacijami, odločevalci pa bi morali razmisliti o takšni spremembi zakonodaje, ki bi omogočala odprte posvojitve in posvojitve istospolnim parom.

\section{Viri}

Blažeka Kokorić, S. (2019). Posvojenje - različite perspektive, isti cilj. Zagreb: Na drugi način, udruga za pružanje psihosocijalne i pedagoške pomoči djeci, mladima i obitelji.

Buda, T. (2017). Pravica do splava (diplomsko delo). Ljubljana: Fakulteta za socialno delo.

Dominelli, L. (1995). Antirasistične perspektive v evropskem socialnem delu. Socialno delo, 34(3), 181-194.

Družinski zakonik (2019). Ur. l. RS, št. 15/17, 21/18 - ZNOrg 22/19 - ZmatR-C.

Geiger, M. (2006). Okrugli stol: društvena stigmatizacija žena - primjer ženskih reproduktivnih prava. Socijalna politika, 13(1), 101-114.

Hafner Fink, M. (2007). Družboslovno raziskovanje: enotnost in raznolikost metod. Ljubljana: Fakulteta za družbene vede.

Hrvaški zavod za javno zdravstvo (2020). Pridobljeno 16. 5. 2020 s https://www.hzjz.hr/

Indeks (2019a). Hrvatska i Poljska: zemlje iz kojih žene bježe radi pobačaja. Pridobljeno 16.

5. $2020 \mathrm{~s} \mathrm{https://www.index.hr/vijesti/clanak/hrvatska-i-poljska-zemlje-iz-kojih-zene-bje-}$ ze-radi-pobacaja/2101511.aspx

Indeks (2019b). Hrvatice masovno odlaze na pobačaj u Sloveniju. Pridobljeno 16. 5. 2020 s https://www.index.hr/vijesti/clanak/hrvatice-masovno-odlaze-na-pobacaj-u-sloveniju/2079120.aspx

Inštitut za javno zdravje (2020). Pridobljeno 16. 5. 2020 s https://podatki.nijz.si/pxweb/sl/ NIJZ\%20podatkovni\%20portal/?px_language=sl\&px_db=NIJZ\%20podatkovni\%20portal\&rxid=d084241e-c0d9-4483-9314-4d845049b2ed

Klun, M. (2008). Posvojitev otrok kot oblika socialnega starševstva (diplomsko delo). Ljubljana: Fakulteta za socialno delo.

Knežević, K. (2015). Abortus u Hrvatskoj spada u sivu zonu. Pridobljeno 16. 5. 2020 s https:// www.pariter.hr/abortus-u-hrvatskoj-spada-u-sivu-zonu/

Laklija, M. (2011). Pristupi udomiteljskoj skrbi za djecu u svojetu i čimbenici koji utječu na ishode udomiteljstva. Socijalna politika, 18(3), 291-309.

Maleš, D. (2015). Kako smo postali obitelj. Posvojenje - dio moje priče. Zbornik radova. Zagreb: » Na drugi način «, udruga ta pružanje psihosocijalne i pedagoške pomoči djeci, mladima i obitelji.

Martinović, D. (2020). Intervju: LGBTIQ osobe žele postati roditelji iz vrlo sličnih razloga kao i heteroseksualna večina. Pridobljeno 14. 5. 2020 s https://www.crol.hr/index.php/ zivot/9886-intervju-lgbtiq-osobe-zele-postati-roditelji-iz-vrlo-slicnih-razloga-kao-i-heteroseksualna-vecina

Mesec, B. (2017/2018). Metodologija raziskovanja v socialnem delu 2: kvalitativne raziskave. Ljubljana: Fakulteta za socialno delo.

Mesec, B., Rape Žiberna, T., \& Rihtar, L. (2009). Načrtovanje raziskave (študijsko gradivo za interno uporabo). Ljubljana: Fakulteta za socialno delo. 
Obiteljski zakon (2015). NN 103/2015.

Rapoša Tajnšek, P., Miloševič Arnold, V., Čačinovič Vogrinčič, G., Rozman, V., Radonjič, N., Bole, M., Kovačec, A., Mikolič, M., \& Rajšel, S. (2002). Postopki, organizacija in standardi na področju posvojitev. Socialno delo, 41(1), 1-42.

Sedlar, E. E. (2017). Hrvatske muke po posvajanju: birokracija, diskriminacija i godine čekanja. Pridobljeno 16. 5. 2020 s https://www.crol.hr/index.php/zivot/9005-hrvatske-muke-po-posvajanju-birokracija-diskriminacija-i-godine-cekanja? $\mathrm{rCH}=2$

Udruga » Na drugi način « (b. d.). Udruga za pružanje psihosocijalne i pedagoške pomoći djeci, mladima i obitelji. Pridobljeno 21. 5. 2020 s https://nadruginacin.hr/

Zakon o liječništvu (2003). NN 121/03, 117/08. Pridobljeno 23. 2. 2021 s https://www.zakon. $\mathrm{hr} / \mathrm{z} / 405 /$ Zakon-o-lije\%C4\%8Dni\%C5\%A1tvu

Zakon o ljekarništvu (2003). NN 121/03, 142/06, 35/08, 117/08. Pridobljeno 23. 2. $2021 \mathrm{~s}$ https://www.zakon.hr/z/409/Zakon-o-ljekarni\%C5\%A1tvu

Zakon o registraciji istospolne partnerske skupnosti (2005). Ur. l. RS, št. 65/05, 55/09- odl. US, 18/16- odl. US,33/16- ZPZ in 68/16- ZPN. Pridobljeno 23. 2. 2021 s http://www.pisrs.si/Pis.web/pregledPredpisa?id=ZAKO4335

Zakon o sestrinstvu (2003). NN 121/03, 117/08, 57/11. Pridobljeno 23. 2. $2021 \mathrm{~s} \mathrm{https://}$ www.zakon.hr/z/407/Zakon-o-sestrinstvu

Zakon o životnom partnerstvu osoba istog spola (2014). NN 92/14, 98/19. Pridobljeno 23. 2. $2021 \mathrm{https://www.zakon.hr/z/732/Zakon-o- \% C5 \% BEivotnom-partnerstvu-osoba-is-}$ tog-spola

Zaviršek, D. (2012). Notranje in meddržavne posvojitve: od osebnih izkušenj do dobre prakse. Priročnik za razvijanje novih strokovnih kompetenc v socialnem varstvu. Ljubljana: Fakulteta za socialno delo.

Zorn, J. (2003). Antirasistična perspektiva v socialnem delu: kako prepoznati rasizem v vsakdanjem življenju in kulturna kompetentnost služb. Socialno delo, 42(4/5), 303-310.

Žganec, N., \& Miljenović, A. (2011). Multikulturalizam u socijalnom radu. Socijalna politika, 18(3), 311-330. 
